\title{
Penyidikan Tindak Pidana Korupsi Di Wilayah Hukum Kejaksaan
}

\author{
Hadi Tuasikal \\ Fakultas Hukum, Universitas Muhammadiyah Sorong \\ Email : Hadilessytuasikal@gmail.com
}

\begin{abstract}
Abstrak
Indonesia merupakan salah satu negara dengan jumlah kasus korupsi yang terbilang cukup banyak. Secara harafiah korupsi merupakan sesuatu yang busuk, jahat, dan merusak. Sebagaimana terjadi dalam praktik, penyidikan kasus korupsi dilakukan oleh Polri, Kejaksaan atau Komisi PemberantasanKkorupsi. Untuk Polri dan KPK dasar hukum kewenangan Penyidikan tindak Pidana korupsi sudah jelas, yaitu Polri berdasarkan Undang-undang Nomor 8 Tahun 1981 Tentang Kitab Undang-undang Hukum Acara Pidana (KUHAP) serta Undang-undang Nomor 2 Tahun 2002 Tentang Kepolisian Republik Indonesia, dan KPK berdasarkan Pada Undang-undang Nomor 30 Tahun 2002 Tentang Komisi Pemberantasan Tindak Pidana Korupsi. Namun untuk Jaksa, ada terdapat banyak Undang-undang yang berkaitan dengan kewenangan Jaksa dalam penyidikan Tindak Pidana Korupsi, sehingga dapat dan telah menimbulkan kebingungan dimasyarakat. Atas dasar inilah, penulis akan memfokuskan untuk membahas penyidikan Tindak Pidana Korupsi oleh Kejaksaan.
\end{abstract}

Kata Kunci : Penyidikan Tindak Pidana Korupsi, Kejaksaan.

\section{PENDAHULUAN}

Dalam KUHP, yang dimaksud korupsi terdapat dalam Buku II Bab XXVIII, khususnya yang mengatur delik yang dilakukan oleh pejabat (dalam arti ambtenaar) yaitu; (a) Pasal 415 KUHP tentang Penggelapan oleh pejabat; (b) Pasal 416 KUHP tentang Pemalsuan buku-buku oleh pejabat; (c) Pasal 418 KUHP tentang Menerima suap; (d) Pasal 423, 425 dan 435 KUHP tentang Menguntungkan diri sendiri secara tidak sah.

Dalam hal penyuapan (Pasal 209, 210, 418, 419 dan 420 KUHP) telah ditarik menjadi delik korupsi menurut Pasal 5, 6, 7, 8, 9 dan 12 dengan Undang-undang Nomor 20 Tahun 2001 yang mengubah Undang-undang Penberantasan Tindak Pidana Korupsi Nomor 31 Tahun 1999. Perkembangan pengertian korupsi dapat dilihat dari rumusan korupsi itu sendiri, yaitu; (1) Rumusan korupsi dari sisi pandang teori pasar bahwa seseorang pengabdi Negara (pegawai negeri) yang berjiwa korup menganggap kantor/instansinya sebagai perusahaan dagang, dimana pendapatannya akan diusahakan semaksimal mungkin.; (2) Rumusan yang menekankan titik berat pejabat pemerintah.; (a) Perkataan "korupsi" dikaitkan dengan perbuatan penyuapan yang berkaitan dengan penyalahgunaan wewenang atau kekuasaan sebagai akibat adanya pertimbangan 
dari mereka yang memegang jabatan bagi keuntungan pribadi.; (b) Seorang pejabat pemerintah dikatakan "korup" apabila ia menerima uang yang dirasakan sebagai dorongan untuk melakukan sesuatu yang bisa dilakukan dalam tugas jabatannya pada hal ini selama menjalankan tugasnya seharusnya tidak boleh berbuat demikian. Atau dapat berarti menjalankan kebijaksanaannya secara sah untuk alasan yang tidak benar dan dapat merugikan kepentingan umum. yang menyalahgunakan kewenangan dan kekuasaan.; (c) Korupsi sebagai perilaku yang menyimpang dari kewajiban-kewajiban normal suatu peran instansi pemerintah, karena kepentingan pribadi (keluarga, golongan, kawan, teman), demi mengejar status dan gengsi, atau melanggar peraturan dengan jalan melakukan atau mencari pengaruh bagi kepentingan pribadi.

Hal itu mencakup tindakan seperti: penyuapan (memberi hadiah dengan maksud hal-hal menyelewengkan seseorang dalam kedudukan pada jawatan dinasnya); nepotisme (kedudukan sanak-saudaranya sendiri didahulukan, demikian pula khususnya dalam pemberian jabatan atau memberikan perlindungan dengan alasan-alasan hubungan asal-usul dan bukannya berdasarkan pada pertimbangan prestasi), penyalahgunaan secara tidak sah menggunakan sumber penghasilan Negara untuk kepentingan / keperluan pribadi.; (d) Rumusan Korupsi dari sisi sosiologis.

Pengkajian makna korupsi secara sosiologis, yaitu terjadinya korupsi adalah apabila seorang pegawai negeri menerima pemberian yang disodorkan oleh seorang dengan maksud mempengaruhi agar memberikan perhatian istimewa pada kepentingan-kepentingan si pemberi. Menurut Arief Sritua (1986:5) korupsi menciptakan 4 efek negatif yang telah melanda kehidupan sosial ekonomi. Pertama, perkembangannya naluri konsumtif ke seluruh lapisan masyarakat yang ditimbulkan oleh pelemparan uang panas atau pembelanjaan pendapatan gelap (black income) oleh para pelaku korupsi dan demonstration effect yang menyertainya.

Kedua, pengalihan sumber-sumber nasional ke luar negeri oleh pelaku-pelaku korupsi disebabkan adanya kekhawatiran timbulnya gejolak sosial yang eksplosif di dalam negeri. Ini membuat kemampuan ekonomis Negara-negara dengan pemerintahan yang korup sangat lemah dalam memenuhi tuntutan-tuntutan masyarakat dalam proses pembangunannya.Ketiga, pergeseran pendapatan yang bersifat semakin regresif setelah memperhitungkan pendapatan dari hasil korupsi yang tidak tercatat; Pendapatan dari hasil korupsi dan penyimpangan-penyimpangan lain, yang bersifat terselubung dan diselubungkan, menyebabkan pendapatan ini tidak dapat masuk dalam jaringan objek perpajakan langsung. Keempat, penyempitan sosial dalam pemanfaatan jasa hartaharta sosial atau barang-barang dan jasa-jasa umum. Ini terjadi sebagai akibat berlangsungnya 
suatu proses penentuan harga barang dan jasa yang tidak wajar dalam masyarakat yang tinbul dari adanya ketidakwajaran disegi penyediaan dan permintaan.

Penegak hukum dapat dibedakan dalam pengertian luas dan pengertian yang sempit.; (a) Dalam arti luas, penegak hukum adalah setiap orang yang mentaati hukum.; (b) Dalam pengertian sempit terbatas pada orang-orang uang diberi wewenang memaksa oleh Undang-undang untuk menegakkan hukum.

Dalam semua yurisdiksi hukum didunia, baik dalam tradisi Anglo Saxon, atau tradisi Eropa Kontinental, jaksa merupakan tokoh utama dalam penyelenggaraan peradilan pidana, karena ia memainkan peranan penting dalam peoses pembuatan dakwaan /tuntutan. Sekalipun polisi lebih terlatih dalam mengumpulkan bukti-bukti di tempat terjadinya kejahatan, pun polisi memiliki komposisi sumber daya manusia dan perlengkapan yang lebih baik, mereka tetap tergantung kepada jaksa dan tetap memerlukan nasihat dan pengarahan jaksa.

Salah satu sebabnya mungkin karena umumnya Jaksa lebih mahir dalam masalah yuridis dan memiliki hak utama yang eksklusif dalam menghubungi pengadilan. Peran kejaksaan adalah sebagai penegak hukum yang diatur dalam Undang-undang Nomor 16 Tahun 2004 Tentang Kejaksaan RI. Dalam Pasal 35, Jaksa Agung mempunyai tugas dan wewenang; (1) Menetapkan serta mengendalikan kebijakan penegakan hukum dan keadilan dalam ruang lingkup tugas dan wewenang kejaksaan; (2) Mengoordinasikan penanganan perkara pidana tertentu dengan instansi terkait berdasarkan undang-undang yang pelaksanaan koordinasinya ditetapkan oleh Presiden.

Penjelasan ayat ini adalah; (1) Yang dimaksud dengan "perkara pidana tertentu” adalah perkara-perkara pidana yang dapat meresahkan masyarakat luas, dan atau dapat membahayakan keselamatan negara, dan atau dapat merugikan perekonomian negara; (2) Yang dimaksud dengan “instansi terkait” adalah instansi yang secara fungsional terkait dengan penangan perkara pidana tertentu, baik badan penegak hukum maupun instansi pemerintah lainnya, dalam hal ini tidak termasuk badan peradilan; (3) Penetapan oleh Presiden tentang pelaksanaan koordinasi sama sekali tidak mengurangi asas kekuasaan kehakiman yang merdeka sebagaimana dimaksud dalam Undang-undang Nomor 14 Tahun 1970 yang telah di ubah dengan Undang-Undang Nomor 48 tahun 2009 tentang Kekuasaan Kehakiman dan tetap memperhatikan asas-asas hukum yang berlaku demi kepastian hukum.

Walaupun didalam Pasal 32 huruf a dan b sama sekali tidak disinggung atau dikatakan mengenai Undang-undang Korupsi, didalam penjelasan pasalnya sangat jelas bahwa yang 
dimaksud dengan "Perkara pidana tertentu yang dapat merugikan perekonomian Negara" menjurus kepada pengertian Undang-undang Pemberantasan Tindak Pidana Korupsi. dengan demikian, kejaksaan menegaskan perannya sebagai instansi atau lembaga yang memegang dan melakukan inisiatif koordinasi didalam tindakan-tindakan penegakan hukum, khisisnya pada perkara-perkara tindak pidana korupsi. Dalam prakteknya, pelaksanaan koordinasi tersebut diteruskan dan dilegitimasi dari Undang-undang Nomor 3 Tahun 1971 tentang Pemberantasan Tindak Pidana Korupsi, sehingga jaksa menjalankan tugas.

Trend perkembangan kasus Korupsi semakin hari semakin meningkat. bahkan dewasa ini berkembang opini publik bahwa korupsi sudah menjelma menjadi suatu budaya baru, dalam arti telah menguasai tingkah laku (behavior) bukan saja birokrasi negara, tetapi juga dunia usaha dan seluruh lapisan masyarakat. tingginya angka korupsi akan merugikan kepentingan pembangunan secara keseluruhan. hampir disetiap bagian kehidupan, selalu ada praktek korupsi. mulai dari bawahan sampai atasan, dari pejabat sampai pegawai rendahan, dibidang perdagangan, dibidang pemerintahan, bahkan dalam bidang pendidikan pun terlihat praktek-praktek korupsi.

Korupsi sangat dipengaruhi oleh prilaku masyarakat. Masyarakat yang hidupnya normal, menerima apa adanya dalam kehidupan sehari-hari alias kurang mendapatkan tekanan-tekanan sosial, ekonomi dan politik yang berat akan lebih terbebas dari perilaku korupsi. Sedangkan, masyarakat yang tinggi tekanan sosial, ekonomi dan politik, akan lebih mudah melakukan tindakan-tindakan korupsi. mentalitas ingin cepat kaya, ingin cepat sukses, bergaya instan akan rawan berperilaku korup ketimbang masyarakat yang mencintai hasil lewat proses kerja yang matang.

Banyak kasus korupsi yang terjadi di Indonesia, berdasarkan pemantauan ICW selama 2008, terdapat 194 perkara Korupsi dengan 444 terdakwa yang diperiksa dan divonis oleh pengadilan di seluruh Indonesia. di tingkat pengadilan negeri ada 159 perkara, banding di pengadilan tinggi 10 perkara, dan kasasi di Mahkamah Agung 25 perkara. Nilai kerugian negara dari perkara-perkara itu mencapai Rp 11,7 triliun. Dari 444 terdakwa korupsi yang telah diperiksa dan diputus, sebanyak 277 terdakwa (62,38 persen) divonis bebas pengadilan. Hanya 167 terdakwa (37,61 persen) yang akhirnya divonis bersalah. namun, ICW melihat, dari 167 terdakwa korupsi yang akhirnya diputuskan bersalah, vonisnya belum memberikan efek jera bagi pelaku korupsi. Terdakwa yang divonis di bawah 1 tahun penjara sebanyak 78 terdakwa, di atas 1,1 tahun hingga 2 tahun sebanyak 55 terdakwa, divonis 2,1 tahun hingga 5 tahun sebanyak 18 terdakwa, dan divonis 5,1 tahun hingga 
10 tahun sebanyak 5 terdakwa. Hanya satu terdakwa yang divonis di atas 10 tahun alias 0,22 persen. Malah ada 10 terdakwa yang divonis percobaan. Rata-rata vonis penjara yang dijatuhkan pengadilan umum 5,82 bulan penjara atau 1 tahun 3 bulan penjara. pada tahun-tahun sebelumnya, kasus korupsi yang divonis bebas pengadilan umum memang cukup besar. ironisnya, kata ICW, dari 277 terdakwa, ada 121 terdakwa yang divonis bebas justru saat ditangani Mahkamah Agung. Ini sangat kontras dengan kasus-kasus korupsi yang ditangani Pengadilan Tindak Pidana Korupsi.

ICW mencatat, selama 2008, terdapat 27 perkara dengan 31 terdakwa yang diperiksa dan diputus Pengadilan Tindak Pidana Korupsi. Seluruhnya divonis bersalah dan tidak ada satu pun yang divonis bebas. Rata-rata terdakwa korupsi divonis Pengadilan Tindak Pidana Korupsi selama 50-90 bulan penjara atau 4,24 tahun penjara. Vonis paling berat di Pengadilan Tindak Pidana Korupsi, yaitu dalam perkara suap yang dilakukan oleh Artalyta Suryani terkait dengan perkara korupsi BLBI Sjamsul Nursalim dengan terdakwa Urip Tri Gunawan, yang divonis 20 tahun penjara. Sedangkan paling ringan adalah dalam kasus Bupati Minahasa Utara Vonnie Anneke Panambunan, yang divonis 1 tahun 6 bulan penjara. Soal kinerja Mahkamah Agung Tahun 2008, ICW menilai reformasi di lembaga ini masih gagal. Kenaikan tunjangan khusus atau remunerasi hingga 100 persen pada 2008 ternyata tidak banyak mengubah keadaan. Menurut ICW, pantas jika peradilan Indonesia mendapat predikat sebagai peradilan terburuk dari 12 peradilan di Asia versi Political and Economic Risk Consultancy/PERC di Hong Kong, September 2008.; (1) Bagaimanakah Pelaksanan Penyidikan Tindak Pidana Korupsi yang dilakukan oleh Kejaksaan Negeri sorong Papua barat ?; (2) Apakah kendala yang dihadapi Kejaksaan Negeri sorong Papua barat dalam melakukan Penyidikan Tindak Pidana Korupsi ?; (3) Bagaimanakah upaya yang dilakukan oleh Kejaksaan Negeri Sorong Papua barat Atas Pengembalian Kerugian Keuangan Negara dalam Perkara Tindak Pidana Korupsi ?

Metode Penelitian Hukum Menurut Philipus M. Hadjon (1994:7-8), disebutkan sebagai berikut : "Suatu pemelihan atas metode yang senantiasa dibatasi oleh perumusan masalah, objek yang akan diteliti dan tradisi keilmuan itu sendiri”. Tipe penelitian yang digunakan dalam penulisan ini adalah bersifat Yuridis Normatif dan Yuridis Empiris.

\section{PEMBAHASAN}

\section{Pengertian Korupsi}


Menurut asal katanya, korupsi berasal dari bahasa latin “corruptio”, “corruption” (inggris) dan "corruptive" (belanda), arti harfiahnya menunjukkan pada suatu perbuatan yang rusak, busuk, tidak jujur yang dikaitkan dengan keuangan Dalam Black's Law Dictionary, korupsi adalah perbuatan yang dilakukan dengan maksud untuk memberikan suatu keuntungan yang tidak resmi dengan hak-hak dari pihak lain secara salah menggunakan jabatannya atau karakternya untuk mendapatkan suatu keuntungan untuk dirinya sendiri atau orang lain, berlawanan dengan kewajibannya dan hak-hak dari pihak-pihak lain.(Sudarto,1976:1)

Syeid Hussein Alatastas, mengembangkan 7 (tujuh) tipologi korupsi sebagai berikut; (1) Korupsi transaktif, yaitu korupsi yang terjadi atas kesepakatan diantara seorang donor dengan resipien untuk keuntungan kedua belah pihak; (2) Korupsi ekstortif, yaitu korupsi yang melibatkan penekanan dan pemaksaan untuk menghindari bahaya bagi mereka yang terlibat atau orang-orang yang dekat dengan pelaku korupsi; (3) Korupsi investif, yaitu korupsi yang berawal dari tawaran yang merupakan investasi untuk mengantisipasi adanya keuntungan dimasa mendatang; (4) Korupsi nepotistic, yaitu korupsi yang terjadi karena perlakuan khusus baik dalam pengagkatan kantor publik maupun pemberian proyek-proyek bagi keluarga dekat; (5) Korupsi otogenik, yaitu korupsi yang terjadi ketika seorang pejabat mendapat keuntungan karena memiliki pengetahuan sebagai orang dalam (insiders information) tentang berbagai kebijakan publik yang seharusnya dirahasiakan; (6) Korupsi supportif, yaitu perlindungan atau penguatan korupsi yang menjadi intrik kekuasaan dan bahkan kekerasan; (7) Korupsi defentif, yaitu korupsi yang dilakukan dalam rangka mempertahankan diri dari pemerasan.

Dalam kamus-kamus bahasa Indonesia ataupun kamus bahasa yang lainnya maka perbuatan korupsi dapat diartikan sebagai perbuatan bejat, tidak bermoral, jorok, perilaku yang suka disogok dan sebagainya. Hal ini juga tedapat di dalam New World Dictionary of the America Languange (Soedjono Dirdjosisworo,1984:7) dimana perbuatan korupsi mengandung arti yaitu; (1) Suatu perbuatan atau kenyataan yang mana menimbulkan keadaan yang bersifat buruk; (2) Perilaku yang jahat, tercela dan atau kejahatan moral; (3) Bentuk-bentuk ketidakjujuran, penyuapan, kebusukan atau tengik; (4) Hal atau sesuatu yang korup, seperti kata yang dirubah atau diganti secara tidak tepat dalam suatu kalimat; (5) Pengaruh yang menjurus ke hal yang korup.

Seorang Sosiolog (S.Husein Alatas,1981:11) menyebutkan korup sebagai berikut : Fenomena yang tercakup dalam istilah korupsi memiliki model atau tipe yaitu; (1) Seseorang dapat menyebut korup apabila seorang pegawai negeri menerima hadiah atau pemberian yang 
disodorkan oleh seorang pengusaha swasta dengan maksud mempengaruhi agar memberikan suatu perhatian atau perlakuan yang istimewa kepada kepentingan si pemberi; (2) Pemerasan, yakni suatu permintaaan pemberian atau hadiah. Hal seperti ini terdapat dalam pelaksanaan tugas-tugas public; (3) Pengangkatan kepada sanak saudara, teman-teman atau rekan-rekan politik yang pada jabatan-jabatan publik tanpa memandang jasa mereka maupun berharap konsekuensinya pada kesejahteraan publik kita menyebut hal ini dengan tindakan nepotisme.

Adapun ciri-ciri dari perbuatan korupsi oleh Alatas (1981 : 13-14) yang mana dapat diuraikan sebagai berikut; (1) Orang yang mana senantiasa melibatkan lebih dari satu orang; (2) Perbuatan korupsi dapat melibatkan elemen-elemen dan muncul kewajiban dan keuntungan timbal balik; (3) Korupsi pada umunya melibatkan keserba rahasiaan; (4) Mereka yang berpraktek caracara korupsi yang biasanya berusaha untuk menyelubungi perbuatannya dengan berlindung di balik pembenaran hukum yang ada; (5) Pihak yang terlibat korupsi adalah pihak-pihak yang sangat menginginkan keputusan-keputusan yang tegas dan mereka sendiri yang mampu mempengaruhi keputusan tersebut; (6) Setiap bentuk korupsi adalah suatu penghianatan terhadap kepercayaan; (7) Setiap bentuk korupsi melibatkan fungsi ganda yang kontradiktif dari mereka-mereka yang melakukan tindakan-tindakan tersebut; (8) Perbuatan korupsi sangat melanggar norma-norma, tugas dan pertanggung jawaban dalam tuntutan masyarakat.

\section{Pengaturan Tindak Pidana Korupsi Dalam Undang-Undang Tindak Pidana Korupsi.}

Jika diperhatikan dalam Undang-undang Nomor 31 Tahun 1999 dan Undang-undang Nomor 20 Tahun 2002, tindak pidana korupsi itu dapat dilihat dari 2 (dua) segi, yaitu korupsi aktif dan korupsi pasif. Yang dimaksud dengan korupsi aktif adalah sebagai berikut; (a) Secara melawan hukum memperkaya diri sendiri atau orang lain atau korporasi yang dapat merugikan keuangan negara atau perekonomian negara ( Pasal 2 Undang-undang Nomor 31 Tahun 1999); (b) Dengan tujuan menguntungkan diri sendiri atau orang lain atau suatu korporasi menyalahgunakan kewenangan, kesempatan atau sarana yang ada padanya karena jabatanya atau kedudukan yang dapat merugikan keuangan negara atau perekonomian keuangan negara.( Pasal 3 Undang-undang Nomor 31 Tahun 1999); (c) Memberi hadiah atau janji kepada pegawai negeri dengan mengingat kekuasaan atau wewenang yang melekat pada jabatan atau kedudukannya atau oleh pemberi hadiah atau janji yang dianggap melekat pada jabatan atau kedudukan tersebut.( Pasal 4 Undangundang Nomor 31 Tahun 1999); (d) Percobaan, pembantuan dan pemufakatan jahat untuk melakukan tindak pidana korupsi.(Pasal 5 Undang-undang Nomor 31 Tahun 1999); (e) Memberi 
atau menjanjikan sesuatu kepada pegawai negeri atau penyelenggara negara dengan maksud supaya berbuat atau tidak berbuat sesuatu dalam jabatannya yang bertentangan dengan kewajibanya.(Pasal 5 ayat (1) huruf a Undang-undang Nomor 31 Tahun 1999); (f) Memberi sesuatu kepada pegawai negeri atau penyelenggara negara karena atau berhubung dengan sesuatu yang bertentangan dengan kewajibannya dilakukan atau tidak dilakukan dalam jabatanya.(Pasal 5 Ayat (2) huruf b Undang-undang Nomor 20 Tahun 2001); (g) Memberikan atau menjanjikan sesuatu kepada hakim dengan maksud untuk mempengaruhi putusan perkara yang diserahkan kepadanya untuk diadili.(Pasal 6 ayat (1) huruf a Undang-undang Nomor 20 Tahun 2001); (h) Pemborong atau ahli bangunan yang pada waktu membuat bangunan, atau penjual bangunan yang pada waktu menyerahkan bahan bangunan, melakukan perbuatan curang yang dapat membahayakan keamanan orang atau barang,atau keselamatan negara dalam keadaan perang. (Pasal 7 ayat (1) huruf a Undang-undang Nomor 20 Tahun 2001); (i) Setiap orang yang bertugas mengawasi pembangunan atau menyerahkan bahan bangunan, sengaja membiarkan perbuatan curang sebagaimana dimaksud dalam huruf a.(Pasal 7 ayat (1) huruf b Undang-undang Nomor 20 Tahun 2001); (j) Setiap orang yang pada waktu menyerahkan barang keperluan tentara Nasional Indonesia atau kepolisian Negara republik Indonesia melakukan perbuatan curang yang dapat membahayakan keselamatan negara dalam keadaan perang.(Pasal 7 ayat(1) huruf c Undangundang Nomor 20 Tahun 2001); (k) Setiap orang yang bertugas menguasai penyerahan barang keperluan Tentara Nasional Indonesia atau Kepolisian Negara republik Indonesia dengan sengaja membiarkan perbuatan curang yang dapat membahayakan keselamatan negara dalam keadaan perang.(Pasal 7 ayat (1) huruf d Undang-undang Nomor 20 Tahun 2001); (1) Pegawai negeri atau orang lain selain pegawai negeri yang ditugaskan menjalankan suatu jabatan umum secara terus menerus atau sementara waktu, dengan sengaja menggelapkan uang atau surat berharga yang disimpan karena jabatanya, atau membiarkan orang atau surat berharga tersebut.(Pasal 8 Undangundang Nomor 20 Tahun 2001); (m) Pegawai negeri atau selain pegawai negeri yang ditugaskan menjalankan suatu jabatan umum secara terus menerus atau sementara waktu, dengan sengaja memalsukan buku-buku atau daftar-daftar yang khusus untuk pemeriksaan administrasi.(Pasal 9 Undang-undang Nomor 20 Tahun 2001); (n) Pegawai negeri atau orang selain pegawai negeri yang ditugaskan menjalankan suatu jabatan umum secara terus menerus atau sementara waktu, dengan sengaja menggelapkan, menghancurkan, merusakan, atau membuat tidak dapat di pakai barang, akta, surat, atau daftar yang digunakan untuk meyakinkan atau untuk membuktikan di 
muka pejabat yang berwenang, yang dikuasai karena jabatanya, atau membiarkan orang lain menghilangkan, menghancurkan, merusakan, atau membuat tidak dapat dipakai barang, akta, surat atau daftar tersebut.(Pasal 10 Undang-undang Nomor 20 Tahun 2001); (o) Pegawai negeri atau penyelenggara negara yang ; (1) dengan maksud menguntungkan diri sendiri atau orang lain secara melawan hukum, atau dengan menyalahgunakan kekuasaanya memaksa seseorang memberikan sesuatu, atau menerima pembayaran dengan potongan atau mengerjakan sesuatu bagi dirinya sendiri. (Pasal 12 huruf e Undang-undang Nomor 20 Tahun 2001); (2) pada waktu menjalankan tugas meminta, menerima atau memotong pembayaran bagi pegawai negeri penyelenggara negara yang lain atau kas umum tersebut mempunyai utang kepadanya, padahal diketahui hal tersebit bukan merupakan utang.(Pasal 12 huruf f Undang-undang Nomor 20 Tahun 2001); (3) pada waktu menjalankan tugas meminta atau menerima pekerjaan atau penyerahan barang seolah-olah merupakan utang pada dirinya, padahal diketahui bahwa hal tersebut bukan merupakan utang.(Pasal 12 huruf g Undang-undang Nomor 20 Tahun 2001); (4) pada waktu menjalankan tugas telah menggunakan tanah negara diatasnya terdapat hak pakai, seolah-olah sesuai dengan peraturan perundang-undanga telah merugikan orang yang berhak, padahal diketahuinya bahwa perbuatan tersebut bertentangan dengan peraturan perundang-undangan. (Pasal 12 huruf $\mathrm{h}$ Undang-undang Nomor 20 Tahun 2001); (5) baik langsung maupun tidak langsung dengan sengaja turut serta dalam pemborongan, pengadaan, atau persewaan yang pada saat dilakukan perbuatan untuk seluruhnya atau sebagian ditugaskan untuk mengurus atau mengawasinya.(Pasal 12 huruf $\mathrm{i}$ Undang-undang Nomor 20 Tahun 2001); (6) memberi hadiah kepada pegawai negeri dengan mengingat kekuasaan atau wewenang yang melekat pada jabatan atau kedudukannya, atau oleh pemberi hadiah atau janji dianggap melekat pada jabatan atau kedudukan itu.( Pasal 13 Undangundang Nomor 20 Tahun 2001)

Adapun korupsi pasif adalah sebagai berikut : (1) pegawai negeri atau penyelenggara negara yang menerima pemberian atau janji karena berbuat atau tidak berbuat sesuatu dalam jabatannya yang bertentangan dengan kewajibanya.(Pasal 5 ayat(2) Undang-undang Nomor 20 Tahun 2001);(2) Hakim atau advokat yang menerima pemberian atau janji untuk mempengaruhi nasihat atau pendapat yang diberikan berhubung dengan perkara yang diserahkan kepada pengadilan untuk diadili.(Pasal 6 ayat (2) Undang-undang Nomor 20 Tahun 2001); (3) orang yang menerima penyerahan bahan barang keperluan TNI atau Kepolisian Negara Republik Indonesia yang membiarkan perbuatan curang sebagaimana dimaksud dalam ayat (1) huruf a dan c, dipidana 
dengan pidana yang sama sebagaimana dimaksud dalam ayat (1) Undang-undang Nomor 20 Tahun 2001.( Pasal 7 ayat (2) Undang-undang Nomor 20 Tahun 2001); (4) pegawai negeri atau penyelenggara negara yang menerima hadiah atau janji padahal diketahui atau patut diketahui atau patut di duga, bahwa hadiah atau janji iti diberikan karena kekuasaan atau kewenangan yang yang berhubungan dengan jabatannya, atau menurut pikiran orang yang memberikan hadiah atau janji tersebut ada hubungan dengan jabatannya.(Pasal 11 Undang-undang Nomor 20 Tahun 2001); (5). pegawai negeri atau penyelenggara negara yang menerima hadiah atau janji padahal diketahui atau patut diduga, bahwa hadiah atau janji tersebut diberikan untuk menggerakan agar melakukan atau tidak melakukan sesuatu dalam jabatanya yang bertentangan dengan kewajibanya, atau sebagai akibat atau disebabkan karena telah melakukan atau tidak melakukan sesuatu dalam jabatanya yang bertentangan dengan kewajibanya. (Pasal 12 huruf a Undang-undang Nomor 20 Tahun 2001); (6). hakim yang menerima hadiah atau janji, padahal diketahui atau patut di duga, bahwa hadiah atau janji tersebut diberikan untuk mempengaruhi putusan perkara yang diserahkan kepadanya untuk diadili.(Pasal 12 huruf c Undang-undang Nomor 20 Tahun 2001); (7). advokat yang menerima hadiah atau janji padahal diketahui atau patut diduga, bahwa hadiah atau janji itu diberikan untuk mempengaruhi nasehat atau pendapat yang diberikan berhubungan dengan perkara yang diserahkan kepada pengadilan untuk diadili.(Pasal 12 huruf d Undang-undang Nomor 20 Tahun 2001); (8). setiap pegawai negeri atau penyelenggara negara yang menerima gratifikasi yang berhubungan dengan jabatanya dan berlawanan dengan kewajiban atau tugasnya.(Pasal 12 Undang-undang Nomor 20 Tahun 2001)

Demikian pengertian tentang korupsi yang diatur dalam Undang-undang Nomor 31 Tahun 1999 dan Undang-undang Nomor 20 Tahun 2001. Lahirnya Undang-undang Nomor 31 Tahun 1999 adalah menggantikan Undang-undang Nomor 3 Tahun 1971, dan diharapkan mampu memenuhi dan mengantisipasi perkembangan masyarakat dalam rangka mencegah dan memberantas secara lebih efektif bentuk tindak pidana korupsi yang yang sangat merugikan keuangan negara dan perekonomian negara.

Ciri tersebut yang telah dikemukakan Alatas diatas, berdasarkan pengamatan yang dilakukannya. Pandangan-pandangan yang telah dikemukakan ada benarnya karena dalam perkara-perkara tindak pidana korupsi jarang sekali kita temukan pelakunya hanya satu orang, tetapi sering melibatkan lebih dari satu orang. Untuk itulah tindak pidana korupsi sering disebut 
dengan Crime Organizer oleh karena perbuatan tersebut dilakukan secara teratur dan terorganisir serta telah direncanakan.

\section{Sistem Pembebanan Pembuktian Terbalik Dalam Tindak Pidana Korupsi.}

Pada dasarnya, secara normatif bahwa tindak pidana korupsi merupakan kejahatan yang luar biasa (extra ordinary crimes). Apabila hal tersebut dikaji dari pandangan doktrinal, maka, Romly Atmasasmita (2002:25), Menekankan bahwa :

“ Dengan memperhatikan perkembangan tindak pidana korupsi, baik dari sisi kuantitas maupun dari sisi kualitas, dan setelah mengkajinya secara mendalam, tidaklah berlebihan jika dikatakan bahwa korupsi di Indonesia bukan merupakan kejahatan biasa melainkan sudah merupakan kejahatan yang sangat luar biasa. Selanjutnya, jika dikaji dari sisi akibat atau dampak negatif yang sangat merusak tataran kehidupan bangsa Indonesia sejak pemerintahan orde baru sampai saat ini, jelas bahwa perbuatan korupsi merupakan perampasan hak ekonomi dan hak-hak sosial rakyat Indonesia”.

Konsekuensi logis bahwa tindak pidana korupsi merupakan extra ordinary crimes, diperlukan penanggulangan dari aspek yuridis yang luar biasa (extra ordinary enforcement) dan perangkat hukum yang luar biasa pula(extra ordinary measures). Dari dimensi ini, salah satu langkah komperehensif yang dapat dilakukan dalam sistem peradilan pidana indonesia adalah melalui pembuktian yang relative memadai, yaitu diperlukan adanya" pembuktian terbalik" atau“" pembalikan beban pembuktian”.(Lilik Mulyadi,2007:252-253).

Sistem pembebanan pembuktian terbalik dalam hukum pidana indonesia, diadopsi dari hukum pembuktian perkara korupsi dari negara anglo saxon, seperti inggris, singapura, dan Malaysia. Sistem pembebanan pembuktian terbalik hanya diterapkan pada tindak pidana yang berkenaan dengan gratification yang berhubungan dengan suap.(Indriyanto Seno Aji, 2002 : 5).

Jenis pembuktian dalam hukum pidana yang dipenalkan dalam Undang-undang Nomor 31 Tahun 1999 juncto Undang-undang Nomor 20 Tahun 2001 adalah pembuktian terbalik yang merupakan penyimpangan dari pembuktian dalam Kitab Undang-undang Hukum Acara Pidana (KUHAP). Namun demikian, pembuktian terbalik tersebut masih memiliki sifat terbatas dimana Jaksa Penuntut Umum masih diwajibkan untuk melakukan pembuktian atas dakwaan yang diajukannya. Jadi, kedua Undang-undang tersebut tidak semata-mata memberikan terdakwa kesempatan untuk membuktikan dirinya tidak bersalah. perumusan pembuktian terbalik dalam pembuktian tindak pidana korupsi ini sendiri telah mengalami penyempurnaan dari rumusan semula pada Undang-undang Nomor 31 Tahun 1999 sampai dengan rumusan pada Undang- 
undang Nomor 20 Tahun 2001, sehingga menunjukan sifat berimbang antara pembuktian yang dilakukan dengan akibat hukum dari pembuktian bagi si terdakwa itu sendiri.

Pada Pasal 37 ayat (2) Undang-undang Nomor 31 Tahun 1999 sebelumnya dinyatakan bahwa:

"Dalam hal terdakwa dapat membutikan bahwa ia tidak melakukan tindak pidana korupsi, maka keterangan tersebut dipergunakan sebagai hal yang menguntungkan baginya."

Sementara setelah dilakukan perubahan terhadap pasal 37 ayat (2) Undang-undang Nomor

20 Tahun 2001 maka dengan lebih tegas dinyatakan bahwa:

“ Dalam hal terdakwa yang dapat membuktikan bahwa ia tidak melakukan tindak pidana korupsi, maka pembuktian tersebut digunakan oleh pengadilan sebagai dasar untuk menyatakan bahwa dakwaan tidak terbukti."

\section{SIMPULAN}

Bangsa Indonesia pada awal reformasi memiliki suatu harapan adanya perubahan terhadap kondisi kehidupan bangsa, khususnya terhadap penyelesaian kasus-kasus Korupsi yang telah berlangsung, namun kenyataanya hingga saat ini wujud tindakan pemberantasan Korupsi belum terlihat hasilnya secara memuaskan, bahkan tindakan Korupsi makin meningkat baik sisi kuantitas maupun dari sisi kualitas. Oleh karena itu, tidaklah berlebihan bila dikatakan bahwa korupsi di Indonesia bukan merupakan kejahatan biasa (ordinary crimes), tetapi telah menjadi kejahatan luar biasa (extraordinary crimes), maka upaya pemberantasannya tidak lagi dapat dilakukan secara biasa, tetapi harus dilakukan dengan cara-cara yang luar biasa pula.

\section{DAFTAR PUSTAKA}

Adami Chawawi,2008. Hukum Pembultian Tindak Pidana Korupsi. Alumni : Bandung Arief Sritua,1986 Korupsi. Lembaga Studi Pembanguan

Anonim,2010. Kompilasi Perundangan Tentang omisi Pemberantasan Korupsi, Polisi, Dan Jaksa. Cetakan I putaka Yustisia : Jakarta

Djoko Prakoso,1987 Pendidikan, Penuntut Umum, Hakim Dalam Proses Hukum Acara Pidana. Bina Aksara : Jakarta

Lilik Mulyadi,2006. Hukum Acara Pidana Normatif, Teoritis dan Permasalahannya. Jakarta Leden Marpaung,2004. Tindak Pidana Korupsi ; Pemberantasan Dan Pencegahanya. Djambatan : Jakarta

Mardjono Reksodiputro, 2002 Korupsi Dalam Sistem Hukum ” Mencuri Uang Rakyat. Kajian korupsi Di Indonesia. Aksara Foundation : Jakarta

Martiman Prodjohamidjojo,2009 Penerapan Pembuktian Terbalik Dalam Delik Korupsi. Mandar Maju : Bandung 
Marwan Efendy,2005 Kejaksaan Posisi Dan Fungsinya Dari Perspekti Hukum. Gramedia Pustaka Utama : Jakarta

Sudarto,1976.Tindak Pidana Korupsi Di Indonesia. Fakultas Hukum Universitas Diponegoro : Semarang

Syeid Husein Alatas. ( tanpa tahun) Coruption : Its Nature, Cause And Consecuences, Aldershot Brookfield,Vt : Evebury

Wirjono Prodjodikoro, 2003 Asas-Asas Hukum Pidana di Indonesia

Undang-Undang Dasar Negara Republik Indonesia Tahun 1945

Kitab Undang-Undang Hukum Piadana ( KUHP)

Undang-Undang Nomor 8 Tahun 1981 Tentang Kitab Undang-Undang Hukum Acara Pidana (KUHAP)

Undang-Undang Nomor 20 Tahun 2001 Tentang Perubahan Atas Undang-Undang Nomor 31 Tahun 1999 Tentang Pemberantasan Tindak Pidana Korupsi

Undang-Undang Nomor 30 Tahun 2002 Tentang komisi Pemberantasan Tindak Pidana Korupsi

Undang-Undang Nomor 16 Tahun 2004 Tentang Kejaksaan Republik Indonesia

Undang-Undang Nomor 1 Tahun 2006 Tentang Bantuan Hukum Timbal Balik Dalam Masalah Pidana ( selanjutnya disebut UU MLA)

Undang-Undang Nomor 3 Tahun 1971 Tentang Pemberantasan Tindak Pidana Korupsi

Undang-Undang Nomor 11 Tahun 1980 Tentang Tindak Pidana Suap

Undang-Undang Nomor 26 Tahun 2000 Tentang Pengadilan Hak Asasi Manusia

Peraturan Pemerintah Nomor 71 Tahun 2000 Tentang Tata Cara Pelaksanaan Peran Serta Masyarakat Dan Pemberian Penghargaan Dalam Pencegahan Dan Pemberantasan Korupsi 